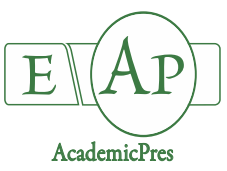

Notulae Botanicae Horti Agrobotanici Cluj-Napoca 48(3):1649-1666

DOI: $10.15835 /$ nbha48311903

Research Article

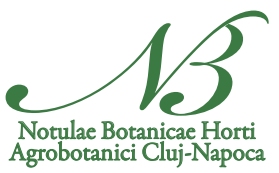

\title{
Occurrence of invasive insects on woody plants in the main green areas from Bucharest city
}

\author{
Flavius BĂLĂCENOIU ${ }^{1,2 *}$, Andrei BUZATU ${ }^{2,3}$, Dragoș TOMA ${ }^{1}$, \\ Alina ALEXANDRU ${ }^{1}$, Constantin NET,OIU ${ }^{3}$ \\ ${ }^{I}$ National Institute for Research and Development in Forestry "Marin Drăcea" Bucharest, Forest Protection Department, 128 B-dul \\ Eroilor,077190,Voluntari, Romania; flavius.balacenoiu@icas.ro(*corresponding author);dragos.toma@icas.ro; \\ alina.alexandru@icas.ro \\ ${ }^{2}$ Transilvania University of Braşov, Faculty of Silviculture and Forest Engineering, 1 Șirul Beethoven, 500123, Braşov, Romania; \\ ${ }^{3}$ National Institute for Research and Development in Forestry "Marin Drăcea" Craiova Station, Forest Protection Department, 24 \\ George Enescu,200144,Craiova, Romania; andrei.buzatu@icas.ro; c_netoiu@yahoo.com
}

\begin{abstract}
In the current context of globalization, biological invasion of alien species has an important impact on environment, economics or human health. Particularly, the spread of these species in urban green areas, is problematic due to several reasons. The aim of this research was to report the presence of invasive insects on woody plants in the main parks across Bucharest (namely Alexandru Ioan Cuza Park, Bucharest Botanical Garden, Cișmigiu Gardens, King Michael I Park, USAMV Campus, Youth Park). Field observations were done during the summer of 2019 (July) and the protocols recently developed by the experts from "Marin Drăcea" National Institute for Research and Development in Forestry were used. It was identified twelve invasive insects species: Aproceros leucopoda (Hymenoptera: Argidae), Cameraria ohridella (Lepidoptera: Gracillariidae), Corythucha arcuata (Hemiptera: Tingidae), Corythucha ciliata (Hemiptera: Tingidae), Cydalima perspectalis (Lepidoptera: Crambidae), Dasineura gledithchiae (Diptera: Cecidomyiidae), Eopineus strobus (Hemiptera: Adelgidae), Macrosaccus robiniella (Lepidoptera: Gracillariidae), Nematus tibialis (Hymenoptera: Tenthredinidae), Obolodiplosis robiniae (Diptera: Cecidomyiidae), Parectopa robiniella (Lepidoptera: Gracillariidae), Prociphilus fraxinifoli (Hemiptera: Aphididae).

Keywords: biological invasions; invasive insects; parks; urban green areas; woody plants

\section{Introduction}

Invasive alien species represent organisms that were introduced by humans (deliberately or accidentally) outside of their natural environment and which have multiplied and started to have negative effects on the new ecosystem (Williamson and Fitter, 1996; Juliano and Lounibis, 2005; EEA, 2013). The phenomenon by which these species are introduced, established, spread and have a negative effect on the native species is defined as biological invasion (Williamson and Fitter, 1996; Davis et al., 2000; Lounibos, 2002, Juliano and Lounibis, 2005; Simberloff et al., 2013).
\end{abstract}

Received: 28 Apr 2020. Received in revised form: 01 Jul 2020. Accepted: 24 Aug 2020. Published online: 31 Aug 2020. 
Against the background of biological invasion due to the current globalization hastening it has been noted that foreign species invasions have caused multiple impacts on the environment, economy or human health (Pimentel et al., 2000; Lovell et al., 2006; Meyrson and Mooney, 2007; Vilà et al., 2010, 2011; Jeschke et al., 2013; Simberloff et al., 2013; Blackburn et al., 2014, Hulme, 2014; Schindler et al., 2015). Invasive alien species represent one of the direct factors involved in the biodiversity loss and ecosystem services changes (EEA, 2013), having a negative influence on native ecosystems, the cultivate ones but also on managed landscapes (Tobin, 2018).

Considering the alien species, it is worth to mention that the terrestrial arthropods were given less attention compared to plants, vertebrates and aquatic organisms, especially given their possible ecological impact (Kenis et al., 2009). From about 1500 alien arthropods which are already established on the European continent, and are part of 33 taxonomic orders, insects represent $87 \%$ of the species (Roques, 2010).

In Europe, the rate of alien insect species reports has almost doubled in recent decades, rising from an average of 10.9 species per year in 1950-1974 to about 19.6 species per year in 2000-2008 (Roques, 2010). These trends that are manifesting at European level can be found in Romania as well, being increasingly visible in recent years after the country became an European Union member due to the freight and human transport increase, but also due to the decrease of customs controls at the border crossing points (Olenici and Duduman, 2016).

In Romania, the studies that addressed invasive forest insect species considered the host trees found in different types of ecosystems: forests, plantations, street tree alignments, isolated trees but also parks and urban areas (Ciceoi et al., 2017; Nețoiu et al., 2018; Olenici et al., 2018; Tomescu et al., 2018).

Given that urban ecosystems are hotspots for biological invasions, the biological invasion domain has given insufficient attention to the invasion dynamics and the challenges facing managers in towns and cities (Gaertner et al., 2017).

A study that summarizes several articles in a special issue based on non-native species in urban environments (Gaertner et al., 2017) states that invasions caused by alien species in urban areas are problematic due to several reasons. Invasive alien species can harmfully affect the ecosystem services on which human society depends (Charles and Dukes, 2007). They can also create ecosystem damages and act as vectors for human or animal diseases (Ertja et al., 2005; Juliano and Lounibos, 2005), causing toxicity and allergic reactions (Netwig et al., 2017) or by emphasizing fire issues at the urban-wildland interface (van Wilgen, 2012). Last but not least, urban environment invasions can create imbalances at the biological communities' level (Kühn and Klotz, 2006; McKinney, 2006; Trentanovi et al., 2013) when they replace regional native species with non-native common species (Godefroid 2001; Wania et al., 2006; Shochat et al., 2010).

Bucharest is the capital of Romania and given the recent urbanization evolution it currently has a share of green space of only $7.5 \%$ of the total area (Eurostat, 2012). At the same time, the average of green areas in Bucharest is only $9.67 \mathrm{sqm} /$ inhabitant, far below the European standards, while cities like Vienna or Stockholm have an average area of green spaces of $70 \mathrm{sqm} /$ inhabitant (Colesca and Alpopi, 2011)

The report regarding the status of environmental factors in Romania (ANPM, 2006) states that in Bucharest there are about forty parks, some of them having a great landscape or historical value, conferring an identity of the capital of which the most important are: Cismigiu Park , King Michael I Park (former Herastrau Park), Tineretului Park, Alexandru loan Cuza (former IOR-Titan) Park, Carol Park.

Therefore, today's Bucharest faces problems such as air pollution, reduced areas of green spaces, the effects of the dreaded continental climate accentuated by climate changes (Chiriac et al., 2009). In this context, in conjunction with the substantial damage caused by the pests found in the main urban parks and ornamental private gardens in Bucharest, it is considered that the existing urban vegetation in the capital should be preserved and protected and the health of the plants should be a high priority for the local authorities (Ciceoi et al., 2017). As a result, through this study we aimed to identify and report invasive insects that are harmful to the woody plants of the main parks and gardens in Bucharest. 


\section{Materials and Methods}

For identifying the invasive insect species on woody plants, we chose the most popular and frequented parks by Bucharest inhabitants, however we also took into account their territorial distribution to be as uniform as possible. In this regard, we considered the following parks:

- Alexandru Ioan Cuza Park was built in the 1970s, in the past being known as IOR Park. It has an area of 48 hectares and it is located in Sector 3 of the capital (44 $25^{\prime} 23.03^{\prime \prime}$ N $26^{\circ} 9^{\prime} 17.45$ "E). The diversity of tree species is not remarkable, but it only has a few types which are found in abundance. The forest species present in the park are both native (oaks, elms, maples) and exotic (Fraxinus pennsylvanica, Platanus sp., honey locust, black locust).

- "Dimitrie Brândză" Botanical Garden was built on the local site in 1884 and is located in Sector 6 of the capital, in the Cotroceni neighbourhood ( $44^{\circ} 26^{\prime} 16.44^{\prime \prime} \mathrm{N} 26^{\circ} 3^{\prime} 49.13^{\prime \prime}$ E). So far, the garden has been affected by various causes such as floods or World War II, but today it covers an area of 18 hectares and has over 10,000 plant species, including 1,000 exotic species out of which a few are found in abundance, such as: horse-chestnut, common box, honey locust, black locust Fraxinus pennsylvanica, Platanus sp., , Eastern white pine.

- Cișmigiu Garden was inaugurated in 1854 , it is located in the centre of the capital ( $44^{\circ} 26^{\prime}$ $13.69^{\prime \prime} \mathrm{N} 26^{\circ} 5^{\prime} 26.15^{\prime \prime} \mathrm{E}$ ) and it is considered the oldest public garden in Bucharest. It covers 16 hectares around a lake and contains numerous rare dendrological species. The most common species are oaks, elms, cherry plum, poplar, willows, maples, European black pine, scots pine. Exotic tree species, such as Platanus sp., horse-chestnut, bald cypress, honey locust, common box can be found as well in Cișmigiu Garden.

- King Michael I Park of Romania, known as Herastrau, is located in the North side of Bucharest, in Sector 1 ( $44^{\circ} 28^{\prime} 14.15^{\prime \prime}$ N $\left.26^{\circ} 04^{\prime} 56.66^{\prime \prime} \mathrm{E}\right)$. It has an area of 187 hectares being considered the largest green area, leisure and tourist objective of the capital. The vegetation of the park consists of a variety of species of native deciduous trees and shrubs (maples, oaks, elms, poplars, willows, ashes) and conifers (fir, spruce). Moreover, the park has in its composition exotic tree species, such as bald cypress, horse-chestnut, Platanus sp., common box, honey locust, Eastern white pine, black locust.

- The USAMV Campus is located in Sector 1 of the capital, in the North side ( $44^{\circ} 28^{\prime} 17^{\prime \prime} \mathrm{N}$ $\left.26^{\circ} 04^{\prime} 01^{\prime \prime} \mathrm{E}\right)$. It covers an area of 38 hectares, and it contains fruit growing experimental didactic fields, a dendrological park and a botanical garden where a multitude of plant species can be found. From a species composition point of view, it includes a lot of native deciduous trees (maple, oaks, elms, poplars, willows, ashes) but also conifers (fir, spruce, Douglas fir, European black pine, scots pine). It also includes numerous exotic tree species, such as Fraxinus pennsylvanica, Platanus sp., common box, honey locust, Eastern white pine, black locust.

- Tineretului Park was inaugurated in 1974 and is located in the South part of the capital, Sector 4 ( $\left.44^{\circ} 24^{\prime} 27.09^{\prime \prime} \mathrm{N} 26^{\circ} 06^{\prime} 20.15^{\prime \prime} \mathrm{E}\right)$. It has a surface of 80 hectares around Tineretului Lake and it is designed as a vast green area where the population can rest and have different recreation activities. The forest vegetation of the park consists of both native species (elms, oaks, maples) and exotic ones (Fraxinus pennsylvanica, Platanus sp., honey locust, black locust).

The six chosen parks were designed for Bucharest citizens' recreation and resting purposes. However, the parks' vegetation is made up of a variety of tree species predisposed to invasive insects, such as: common box, horse-chestnut, plane trees, oaks etc.

To achieve the aim, we studied the invasive insects on woody plants species which were identified in several studies in Romania (Olenici and Duduman, 2016, Ciceoi et al., 2017, Olenici et al., 2018, Nețoiu et al., 2018). Thus, based on the information about the invasive insect species present in Romania, their host species and knowing the tree species present in the six parks in our study, we compiled a list of invasive forest insects 
that can potentially be present in the studied parks. Therefore, we decided that the invasive insect species list to be included in our study would be made up of 12 species (Table 1).

In order to have an efficient and unitary identification work, for each of the 12 species of insects we extracted from the Romanian invasive forest insects` studies (Olenici and Duduman, 2016; Olenici et al., 2018; Nețoiu et al., 2018) the recommended finding method (Table 1).

Also, for each of the 12 invasive insect species, we developed a species identification sheet. In order to ease the field work, in each new species sheet we presented two sections: 1) symptoms of the attack and 2) morphological details of the insect.

Therefore, in the Symptoms of the Attack section we presented pictures showing each species' characteristic attack type such as mines, discolorations, defoliations or galls produced by the insects. For example, for Corythucha arcuata we presented pictures showing both the upper side of oaks` leaves where the discolorations could be observed and the lower side of the leaves where the typical black spots were detected.

Moreover, in the Morphological Details of the Insect section we presented detailed pictures showing all the development stages of the insect: egg, larvae, pupa and adult. For example, for Corythucha arcuata we presented details of all the development stages of the insect through pictures: egg, larvae and adult.

In order to make the observations, we chose a timeframe when all the species in our list could be detected according to the method previously established. Thus, in July 2019, we made observations in King Michael I Park, USAMV Campus and Alexandru Ioan Cuza Park, Tineretului Park, Cișmigiu Garden and Botanical Garden.

Table 1. List of invasive insect species followed, host species and detection method

\begin{tabular}{|c|c|c|c|}
\hline No. & Insect species & Host species & Detection method \\
\hline 1. & Aproceros leucopoda & Ulmus spp. & $\begin{array}{l}\text { characteristic attack of the zigzag leaf }+ \text { the larvae presence } \\
\text { or cocoons on the leaves. }\end{array}$ \\
\hline 2. & Cameraria ohridella & $\begin{array}{c}\text { Aesculus } \\
\text { hippocastanum, Acer } \\
\text { platanoides, } A . \\
\text { pseudoplatanus }\end{array}$ & mines produced on the upper side of the leaves \\
\hline 3. & Corythucha arcuata & Quercus spp. Tilia spp. & $\begin{array}{l}\text { chlorotic discoloration on the upper side of the leaf }+ \\
\text { presence of the insect in different stages of development }\end{array}$ \\
\hline 4. & Corythucha ciliata & Platanus spp. & $\begin{array}{l}\text { chlorotic discoloration on the upper side of the leaf }+ \\
\text { presence of the insect in different stages of development }\end{array}$ \\
\hline 5. & $\begin{array}{c}\text { Cydalima } \\
\text { perspectalis }\end{array}$ & Buxus serpenvirens & $\begin{array}{l}\text { characteristic mode of attack (defoliation) + presence of } \\
\text { the insect in various development stages }\end{array}$ \\
\hline 6. & $\begin{array}{l}\text { Dasineura } \\
\text { gleditschiae }\end{array}$ & Gleditsia triacanthos & through the galls on the leaves \\
\hline 7. & Eopineus strobus & Pinus strobus & $\begin{array}{l}\text { the aphid's presence and white waxy secretions on the } \\
\text { branches of the host species }\end{array}$ \\
\hline 8. & $\begin{array}{l}\text { Macrosaccus } \\
\text { robiniella }\end{array}$ & Robinia pseudacacia & $\begin{array}{l}\text { presence of characteristic mines on the lower side of the } \\
\text { leaves }\end{array}$ \\
\hline 9. & Nematus tibialis & Robinia pseudacacia & $\begin{array}{l}\text { the defoliation produced by them in holes form }+ \text { the } \\
\text { larvae presence on the leaves }\end{array}$ \\
\hline 10. & $\begin{array}{l}\text { Obolodiplosis } \\
\text { robiniae }\end{array}$ & Robinia pseudacacia & the characteristic galls presence on the leaves \\
\hline 11. & Parectopa robiniella & Robinia pseudacacia & $\begin{array}{c}\text { the digitiform type of mines on the upper side of the host } \\
\text { tree leaves }\end{array}$ \\
\hline 12. & $\begin{array}{l}\text { Prociphilus } \\
\text { fraxinifoli }\end{array}$ & Fraxinus pennsylvanica & large malformations formed on the leaves \\
\hline
\end{tabular}


As a result, in each of the six locations we inspected only the host trees mentioned in table 1 that were potentially infested with invasive insect species. The observations were made by ground survey for lower branches, and for the upper branches' binoculars were used. Consequently, on each inspected tree we looked for the presence of possible insect species according to the detection methods specific to each one of them as presented in Table 1.

\section{Results}

During July 2019, observations were made on the itinerary in the main parks in Bucharest: Alexandru Ioan Cuza Park, Botanical Garden, Cişmigiu Garden, King Michael I Park, USAMV Campus and Tineretului Park.

In each park, observations were made based on the list which was prepared previously containing potential present invasive insects. Findings were made starting with the host tree species, the characteristic aspect of the injury as well as the presence of insects in various stages of development. Thus, 12 species of invasive insects on woody plants have been identified (Table 1) as follows: Aproceros leucopoda (Hymenoptera: Argidae), Cameraria ohridella (Lepidoptera: Gracillariidae), Corythucha arcuata (Hemiptera: Tingidae), Corythucha ciliata (Hemiptera: Tingidae), Cydalima perspectalis (Lepidoptera: Crambidae), Dasineura gleditchiae (Diptera: Cecidomyiidae), Eopineus strobus (Hemiptera: Adelgidae), Macrosaccus robiniella (Lepidoptera: Gracillariidae), Nematus tibialis (Hymenoptera: Tenthredinidae), Obolodiplosis robiniae (Diptera: Cecidomyiidae), Parectopa robiniella (Lepidoptera: Gracillariidae), Prociphilus fraxinifoli (Hemiptera: Aphididae).

\section{Aproceros leucopoda (Takeuchi, 1939) (Hymenoptera, Argidae)}

Aproceros leucopoda is an East-Asian species that attacks host trees of the Ulmus spp. The attack is made by larvae that eat the leaves in zigzag pattern (Figure 1), and as the attack gets stronger, they can consume the entire leaf, except for the main rib, which can produce total tree defoliation. The typical "zig-zag" or serpentine pattern produced by the larval feeding on the leaf lamina and also the larvae presence or cocoons on the Ulmus spp. leaves helped us identify the Aproceros leucopoda species (Figure 1). After surveying the six parks in Bucharest, the Aproceros leucopoda species was identified in only two locations, more exactly in the USAMV Campus and Alexandru Ioan Cuza Park. In both locations the invasive insect species Aproceros leucopoda was present on host trees of the Ulmus minor species. In both the locations the species did not cause strong defoliation but only a few leaf consumptions, thus we can say that the species was present, but in so small populations that it can be considered harmless.

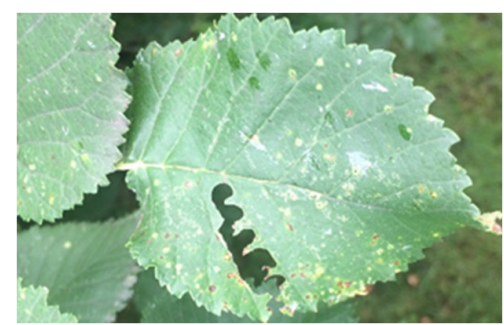

Figure 1. Aspect of attack produced by Aproceros leucopoda în USAMV Campus

\section{Cameraria ohridella (Deschka\&Dimic, 1986) (Lepidoptera, Gracillariidae)}

Cameraria ohridella was first discovery in Macedonia in the 1970s and it was described as a new species in 1986 by Deschka and Dimic. The attack has the form of mines produced by larvae on the horse-chestnut leaves. For identifying the species, we considered the characteristic type of the attack on the host trees of 
Aesculus hippocastanum species, more precisely the mines produced under the upper epiderms of the leaves (Figure 2A). During the observations, Cameraria ohridella species was identified in all the six examined parks: Alexandru Ioan Cuza, Botanical Garden of Bucharest, Cişmigiu Garden, King Michael I Park, USAMV Campus and Tineretului Park. The characteristic aspects of the attack were present on trees of the horsechestnut host species. Moreover, in the six parks the species was found in high population densities, in most cases being present in up to 100 mines per leaf. The trees crowns have a prematurely dried appearance (Figure 2B), in extremely high densities being even prematurely defoliated.
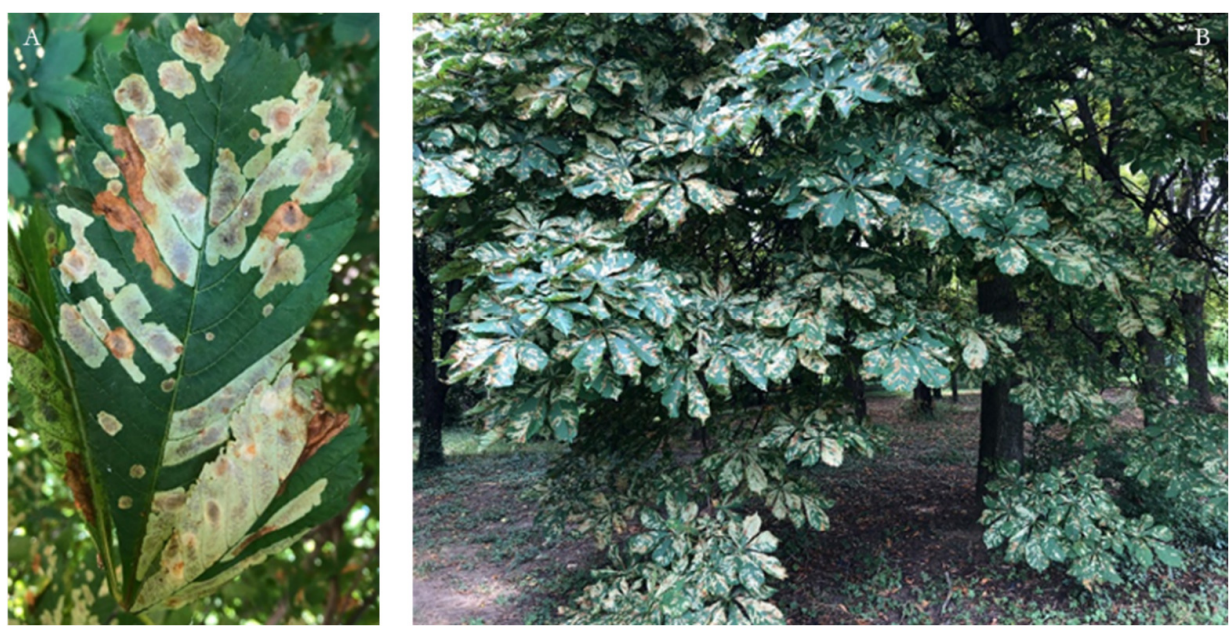

Figure 2. Aspects of attack produced by Cameraria ohridella in the Tineretului Park; (A) mines produced under the upper epiderms of the leaves; (B) crowns of the attacked trees

\section{Corythucha arcuata (Say, 1832) (Hemiptera, Tingidae)}

Corythucha arcuata, originating from North America, is a polyphagous species which mainly feeds on oaks. The attack is produced by both adults and nymphs, and results in a chlorotic discoloration on the upper side of the leaves while on the lower side numerous black spots can be found. This species was identified by the presence of the insect in different stages of development (egg, nymph, adult) (Figure 3A) or after the chlorotic discoloration on the upper side of the leaf (Figure 3B), respectively the black spots characteristic on the lower side of the oaks tree leaves (Figure 3C). Thus, in July 2019 both Corythucha arcuata species individuals as well as characteristic aspects of the attack were found in all the six examined parks. The insect was reported on Quercus robur, Q. cerris, $Q$. variabilis and Tilia tomentosa species host trees. Considering the premature discoloration of the oak leaves attacked by OLB in all six locations under study (Figure 3D), we consider that the pest has produced strong infestations and population density is at high levels.
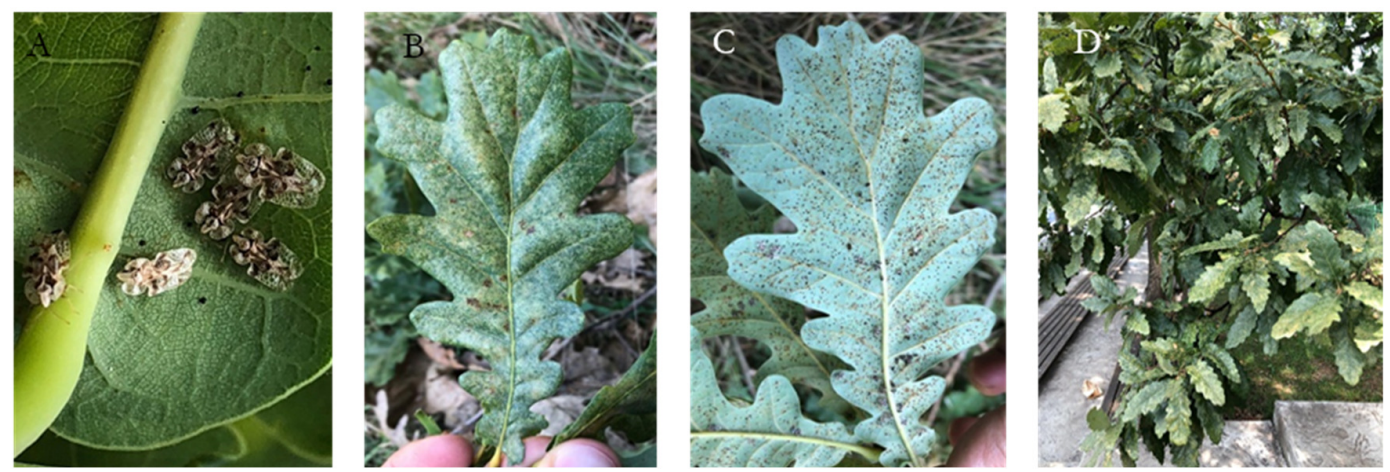

Figure 3. Aspects of attack produced by Corythucha arcuata in IOR Park; (A) adults on oak leaf; (B) upper side of the leaf; (C) lower side of the leaf; (D) leaves of heavily infested trees 


\section{Corythucha ciliata (Say, 1832) (Hemiptera,Tingidae)}

Corythucha ciliata is North America originating species and it is found on Platanus spp. host trees. The characteristic aspect of the attack is represented by chlorotic discoloration on the upper side of the leaves and numerous black spots on the lower side (Figures 4A-C) produced by both nymphs and adults. To detect the Corythucha ciliata species, the same methodology was used as for the Corythucha arcuata species, except that the inspections were carried out on host tree species of the Platanus species. Although the host species was present in all of the six examined locations, we found both Corythucha ciliata specimens and typical aspects of the attack produced by it only in King Michael I Park, Alexandru Ioan Cuza (IOR) Park, the USAMV Campus and the Botanical Garden in Bucharest. Even though the appearance of this species attack is similar with the one produced by Corythucha arcauta, in this case the infestations were very weak except for the ones in Alexandru Ioan Cuza (IOR) Park where the leaf discoloration is significant and the infestation is severe (Figures 4A-C).
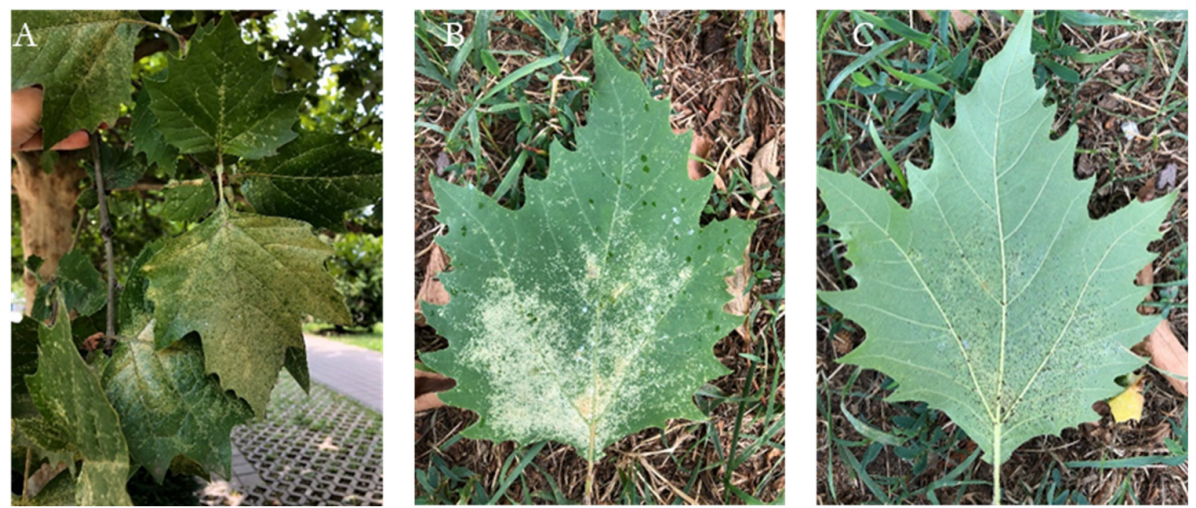

Figure 4. Aspects of attack produced by Corythucha ciliata in IOR Park; (A) the upper side of the leaves as a whole; (B) the upper side of the leaf in detail; (C) the lower side of the leaf

Cydalima perspectalis (Walker, 1859) (Lepidoptera, Crambidae)

Cydalima perspectalis, an East Asian originated species, which can be found on host bush common box. The larvae are feeding with the leaves and shrubs shoots. Depending on the larvae's age and their density, the attack can become very strong reaching total defoliation of the shrubs. Starting from the already known fact that the Cydalima perspectalis species larvae are feeding with the common box leaves and bushes, we made observations in all the selected six parks that had ornamental shrubs of common box. The finding was performed according to the characteristic mode of attack (Figures 5A and 5B) as well as the presence of the insect in various development stages (Figures 5C and 5D). In this way, the Cydalima perspectalis species was found in all four parks out of six in which the host species was present: King Michael I Park, USAMV Campus, Botanical Garden and Cișmigiu Garden in Bucharest. 

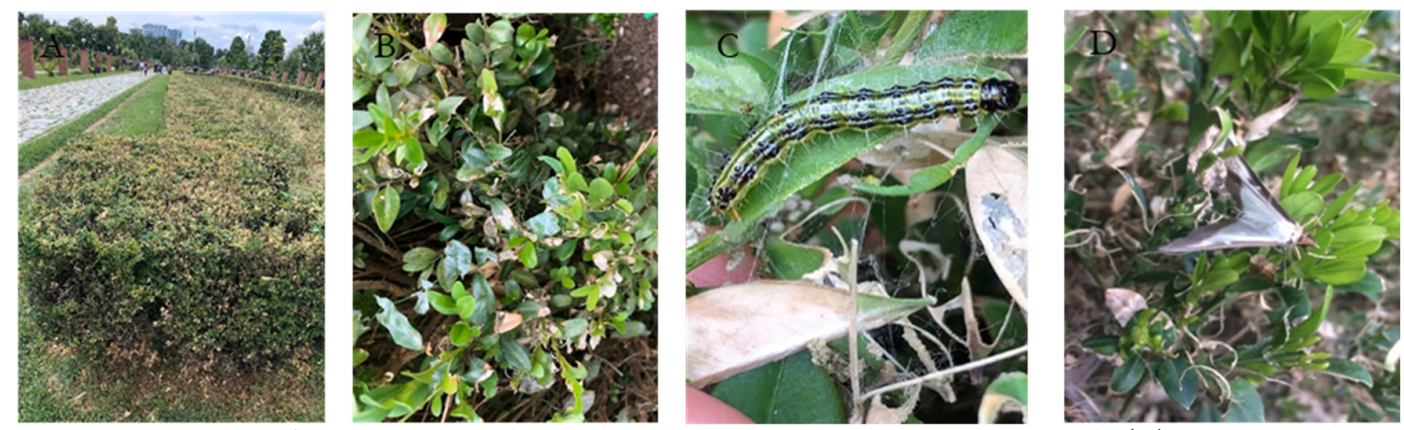

Figure 5. Aspects of attack produced by Cydalima perspectalis in King Michael I Park; (A) typical attack as a whole (B) typical attack in detail; (C) Cydalima perspectlis in larval stage; (D) C. perspectalis in adult stage

Dasineura gleditchiae (Osten Sacken, 1866) (Diptera, Cecidomyiidae)

Dasineura gleditchiae is a North America originating species and it is known as a pest of the honey locust. The attack produced by larvae that are feeding with developing leaves producing in this way small galls resembling pods. After a while these galls dry up and fall producing defoliation of the affected shoot that give an unsightly appearance to the affected trees. Due to the fact that the appearance of the attack was easily visible through the galls on the leaves of the honey locust (Gleditsia triacanthos) similar to small pods (Figure 6A) followed by the premature shaking of the leaves (Figure 6B), it was decided to detect the species presence after this hint. In this way, Dasineura gleditchiae species was identified in all the parks considered for the study: Alexandru Ioan Cuza Park, Botanical Garden in Bucharest, Cişmigiu Garden, King Michael I Park, USAMV Campus and Tineretului Park.
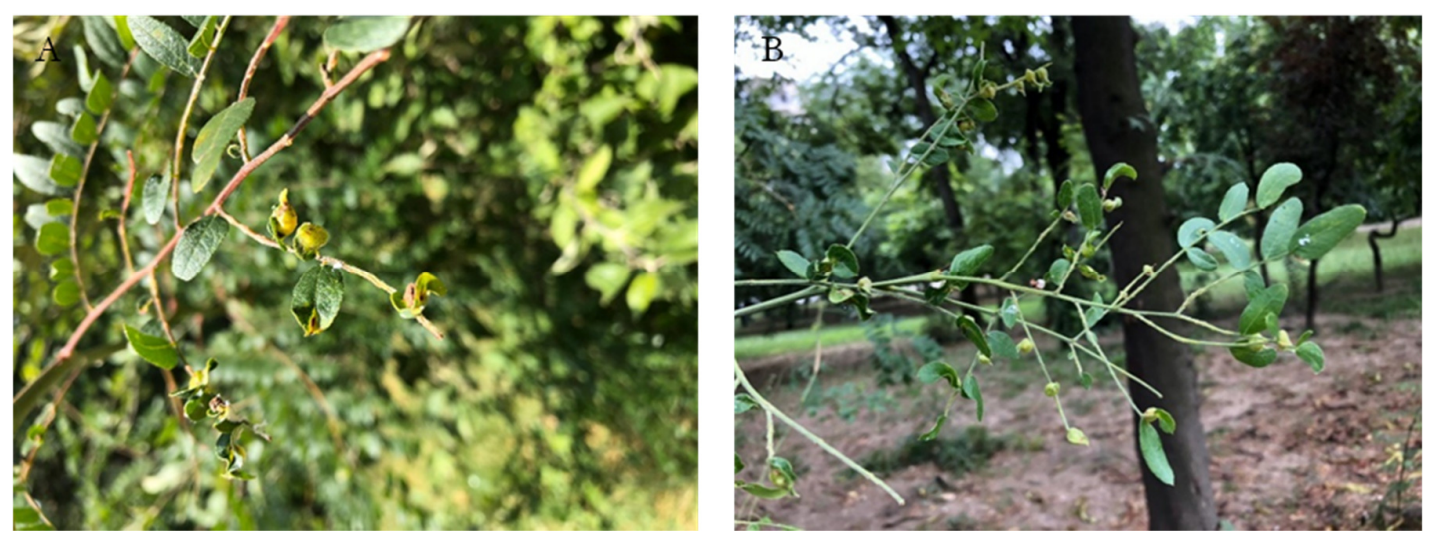

Figure 6. Aspects of attack produced by Dasineura gleditchiae in Cișmigiu Garden; (A) the galls presence on leaves (B) premature leaves fall

Eopineus strobus (Hartig, 1837) (Hemiptera, Adelgidae)

Eopineus strobus is an invasive species originated from North America. Due to the development of aphid's colonies on the host species stem or branches, the aesthetic appearance of the host trees is affected. In order to detect the Eopineus strobus invasive species we identified the characteristic aspects of the attack, more exactly the aphid's presence and white waxy secretions on the branches of the Pinus strobus species (Figure 7 A and 7B). After visiting the six parks considered for study, the Eopineus strobus species was detected in only three of them: USAMV Campus, King Michael I Park and the Botanical Garden, due to the fact that in the other three parks the host species of the insect, Pinus strobus, was not present. 

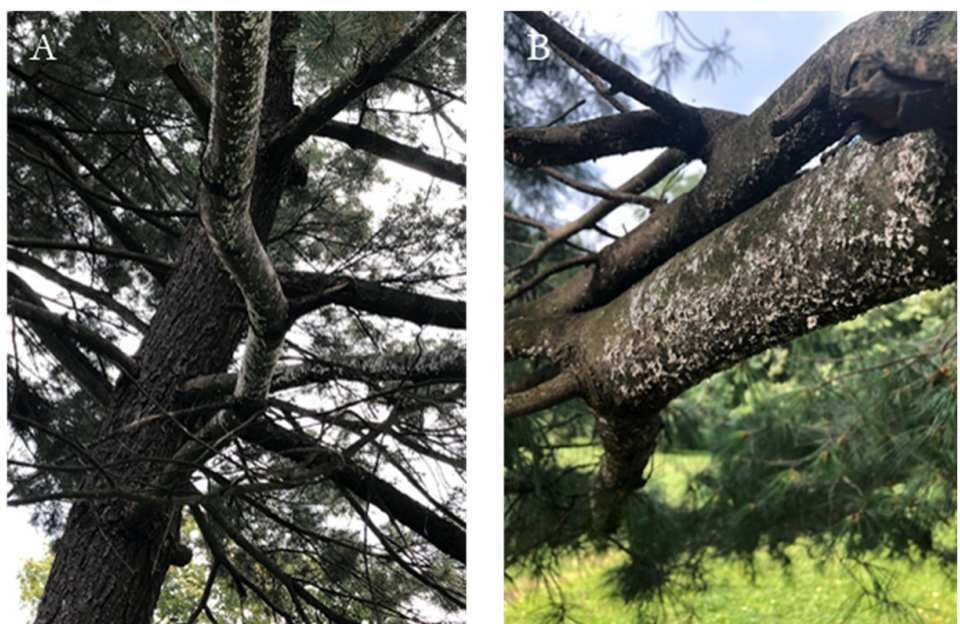

Figure 7. Aspects of attack produced by Eopineus strobus in USAMV Campus; (A) view as a whole; (B) typical attack in detail

\section{Macrosaccus robiniella (Clemens, 1859) (Lepidoptera, Gracillariidae)}

Macrosaccus robiniella is a North America originating species that lives on host trees of the Robinia pseudoacacia species. The injuries are produced by larvae that are developed in the mines produced on the lower side of the black locust leaves, which consumes the entire mesophill until they are fully developed. In order to detect the Macrosaccus robiniella species we identified the characteristic attack, more exactly the presence of characteristic mines on the lower side of the leaves (Figures 8A and 8B). In this way, after checking the six parks included in the study, although the host species was present in all examined locations, we only identified the mentioned species in the King Michael I Park and Alexandru Ioan Cuza Park.
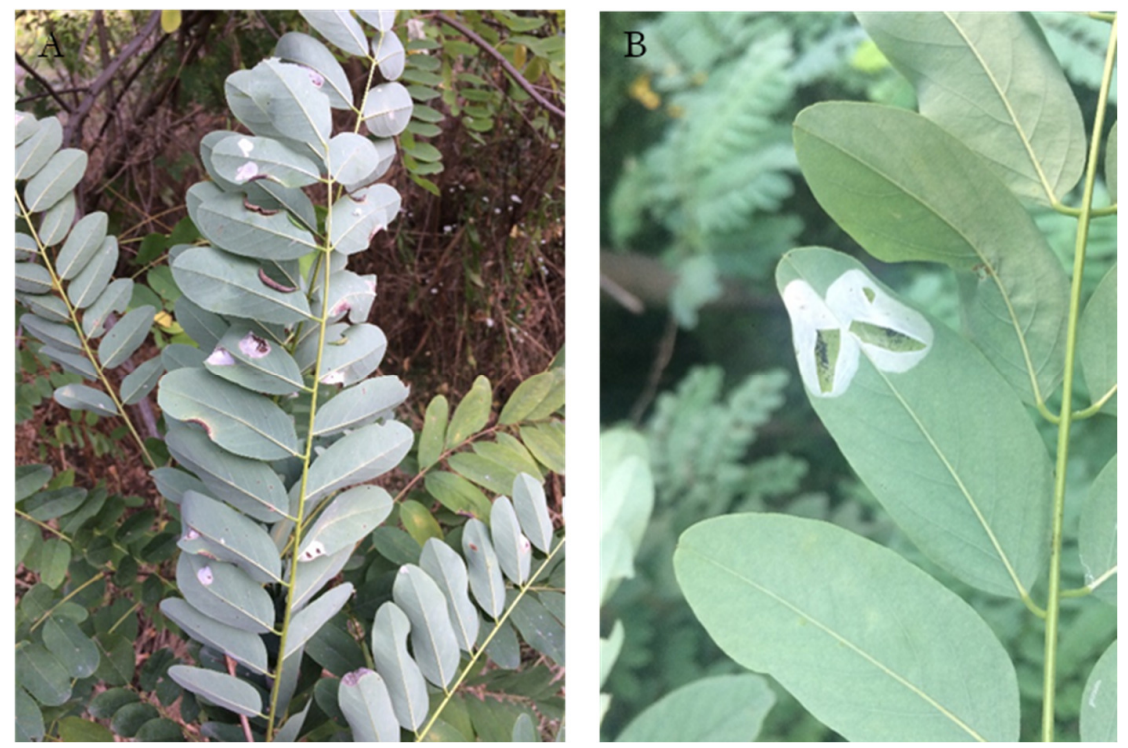

Figure 8. Aspects of attack produced by Macrosaccus robiniella in King Michael I Park (A) view as a whole (B) typical attack in detail

\section{Nematus tibialis (Newman, 1837) (Hymenoptera, Tenthredinidae)}

Nematus tibialis is a North American originating species and its host species is Robinia pseudoacacia. At the beginning the attack is produced by young larvae that consumes an orifice in the black locust leaves and then extend the gnawed portions gradually, reaching the main rib. Identifying this species was made either by 
the larvae presence on the black locust leaves (Figure 9A), or by the defoliation produced by them in holes form (Figure 9B) or even the entire leaf margin to the main rib (Figure 9C). Although the host species was present in all six the locations under study, in July 2019, Nematus tibialis was identified in only three locations: King Michael I Park, Tineretului Park and Bucharest Botanical Garden.
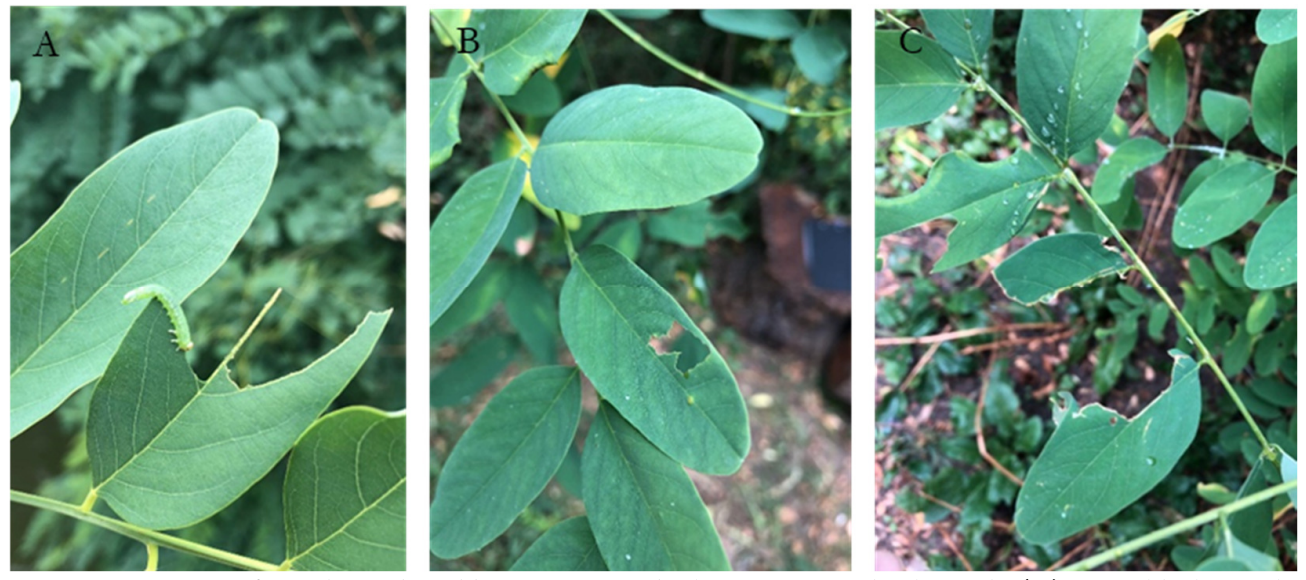

Figure 9. Aspects of attack produced by Nematus tibialis in King Michael I Park; (A) typical holes in the leaf; (B) Typical defoliating up to the main rib of the leaf

\section{Obolodiplosis robiniae (Haldeman, 1847) (Diptera: Cecidomyiidae)}

Obolodiplosis robiniae is originating from Pennsylvania, USA, and it is present on the Robinia pseudoacacia host species. The injury is represented by the galles in which the larvae are developing immediately after the adult's lay eggs on the margins of the black locust leaflets. In order to detect the Obolodiplosis robiniae invasive alien species, we identified the characteristic galls presence on the black locust leaves (Figures 10A and 10B). Thus, Obolodiplosis robiniae was identified in all the six parks under study during the observation period: Alexandru Ioan Cuza (IOR) Park, Bucharest Botanical Garden, Cişmigiu Garden, King Michael I Park, USAMV Campus and Tineretului Park.
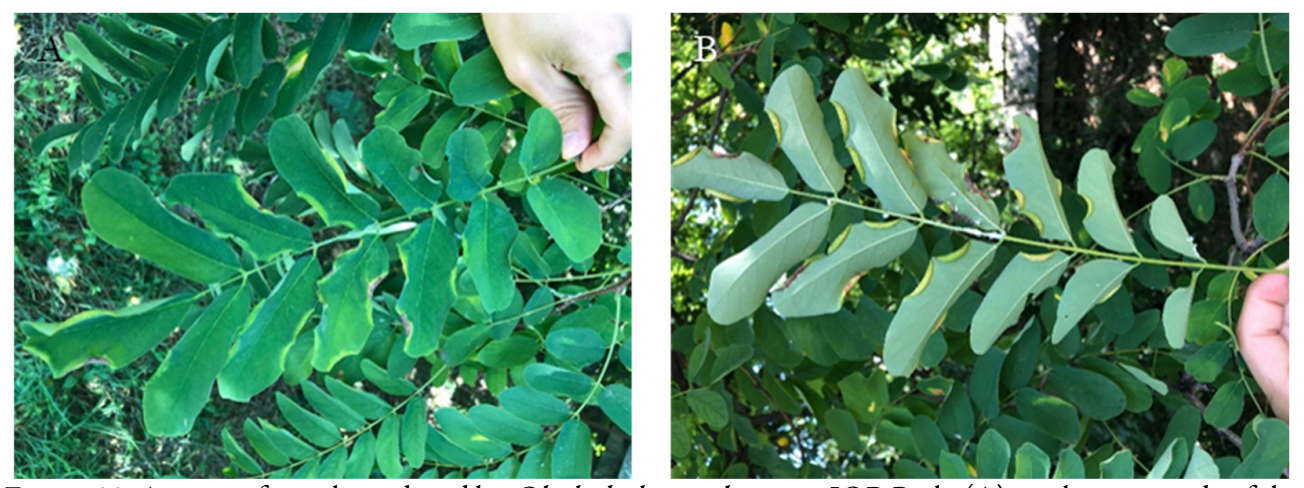

Figure 10. Aspects of attack produced by Obolodiplosis robiniae in IOR Park; (A) on the upper side of the leaves; (B) on the lower side of the leaves

\section{Parectopa robiniella (Clemens, 1863) (Lepidoptera, Gracillariidae)}

Parectopa robiniella, originating in North America, has Robinia pseudacacia as host species. The injuries are caused by larvae that develop in mines on the upper side of the leaflets (Figures 11A and 11B). The identification of Parectopa robiniella species was carried out following the characteristic attack, more precisely the digitiform type of mines on the upper side of the host tree leaves of the black locust. Thus, after visiting the 
six parks in July 2019, Parectopa robiniella was detected in Alexandru Ioan Cuza (IOR) Park, King Michael I Park and Tineretului Park, given that the host species was present in all six locations.
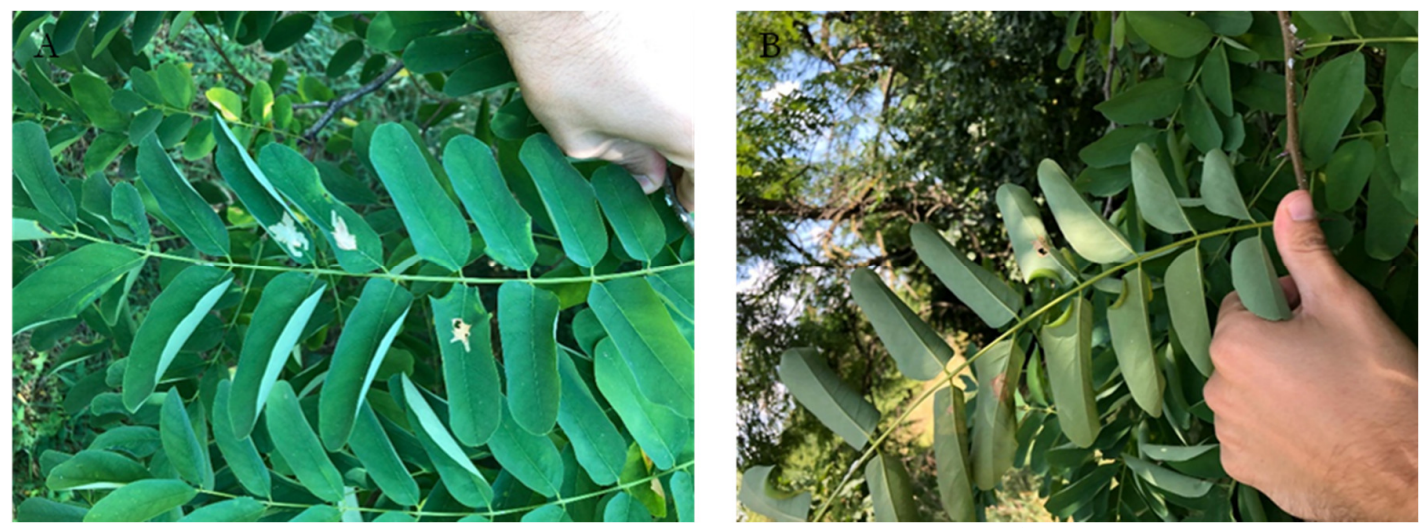

Figure 11. Aspects of attack produced by Parectopa robiniella in IOR Park; (A) on the upper side of the leaves (B) on the lower side of the leaves

\section{Prociphilus fraxinifolii (Riley, 1879) (Hemiptera, Aphididae)}

Prociphilus fraxinifolii, species originating from North America, is an invasive alien pest of ash. Host tree injuries are caused by aphids which develop on the leaves and cause large malformations full of their own defecations (Figures 12A and 12B). In order to detect the species, we were looking at large malformations formed on the green ash leaves (Fraxinus pennsylvanica) inside which excretions of aphids were present. With the exception of the Herastrau Park, the host species was present in all the other five locations. After observing the five parks and through the above described detection method, Prociphilus fraxinifolii was reported as being present on USAMV Campus, Alexandru Ioan Cuza Park and Tineretului Park.
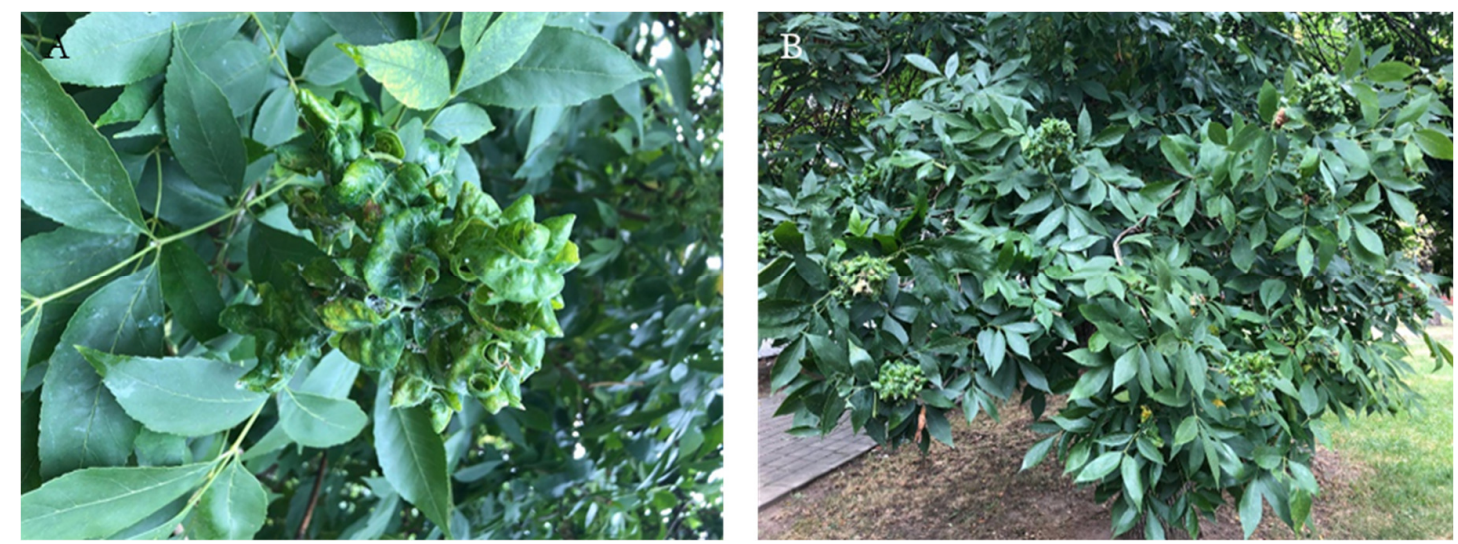

Figure 12. Aspects of attack produced by Prociphilus fraxinifolii in Tineretului Park; (A) malformation caused by aphids; (B) malformations affected tree crown

\section{Discussion}

Of all the invasive insect species on woody plants found in the current study, none are new to Romania, all have been reported before in the country through other studies (Olenici and Duduman, 2016; Olenici et al., 2018; Nețoiu et al., 2018; Tomescu et al., 2018). However, in Bucharest green areas only four species out of the 12 have been reported previously: Cameraria ohridella, Corythucha arcuata, Corythucha ciliata and Cydalima 
perspecalis (Ciceoi et al., 2017; Tomescu et al., 2018), the rest the species being reported for the first time in Bucharest: Aproceros leucopoda, Dasineura gleditchiae, Eopineus strobus, Macrosaccus robiniella, Nematus tibialis, Obolodiplosis robiniae, Parectopa robiniella, Prociphilus fraxinifoli.

Aproceros leucopoda is an East Asia originated species that was reported in Europe for the first time in 2003 in Hungary and Poland and in Romania in 2006 (Blank et al., 2010). In Bucharest, it was detected after its characteristic attack method, in only two of the parks under study, on trees of the host species Ulmus minor. Different than the previous attacks in Romania from 2005-2006, when tree defoliation was between $74 \%$ and 98\% (Blank et al., 2010), this time in Bucharest parks the elm trees were not visibly affected, but we only identified a few leaves with typical zigzag consumption.

Cameraria ohridella is a species which was recently identified and described as a species in the ' 70 s in Macedonia, but the actual origin of it is still questionable given the fact that in North America there are around fifty Cameraria species known (Buszko, 2006). In Romania, it was reported in 1996, in Timisoara (Șandru, 1998). In Bucharest, Cameraria ohridella is one of the invasive insect species that was found in all six inspected parks, confirming the hypothesis that this species is found wherever the horse chestnut is encountered (Olenici and Duduman, 2016). Although in other studies the species has also been reported on trees' leaves such as Acer platanoides L. and A. pseudoplatanus L. (Skuhravy, 1999; Grabenweger and Grill, 2000), in Bucharest parks typical symptoms of Cameraria ohridella species were found on Aesculus hippocastanum host species leaves only.

Corythucha arcuata, a North America originating species was first reported in Europe in 2000, in Italy (Bernardinelli and Zandigiacomo, 2000), and in Romania in 2015 (Don et al., 2016). Moreover, Corythucha arcuata is another species that was found in all six locations investigated, confirming again the hypothesis that Corythucha arcuata exists whenever its host species are present (Jurc and Jurc 2017; Neimorovets et al., 2017; Simov et al., 2018). In five of the locations, the invasive alien species Corythucha arcuata was present on trees of indigenous Quercus or Tilia host species which were already reported in other studies as well (Bernardinelli and Zandigiacomo, 2000; Forster et al., 2005; Dioli et al., 2007; Mutun et al; 2009: Csóka et al., 2013; Dobreva et al., 2013; Hrašovec et al., 2013; Don et al., 2016; Neimorovets et al., 2017; Simov et al., 2018). However, clear aspects of the attack resulting from insect feeding were found on oak species, while on Tilia genus trees only the presence of the insect was observed, without attack signs. Nevertheless, in the Botanical Garden in Bucharest, Corythucha arcuata was found feeding on leaves of the Quercus variabilishost trees species, one that has not been reported in the past.

Corythucha ciliata is a North American species first reported in Europe in 1964, in Italy (Rabitch, 2008), and in Romania in 1990, in Craiova (Kis, 1990). In our study Corythucha ciliata affected only planes trees, even though in the proximity there were other types of trees such as Moraceae, Juglandaceae, Fraxinus which are considered in literature as being hosts for this species (Harbert and Meeker, 1998).

Considering the fact that Corythucha ciliata species causes stronger infestations on trees in parks and gardens than in those found in natural environment (Tatu and Tăușan, 2011) as well as the fact that it is known to invade homes in big populations (Malumphy et al.,2006), we consider that it is necessary to study the species impact on the urban green spaces of Bucharest. To the same extent, we consider that the same attention should be paid to the $C$. arcuata species, especially since in the summer of 2019 the problem of invasion of both species was raised in Bucharest by citizens and the media.

Cydalima perspectalis is a species that has its origins in East Asia and was first reported in Europe in 2006 in Germany (Krüger, 2008) and in Romania, in Bucharest itself, in 2010 (Iamandei, 2010). At this moment, anywhere there is a host species (Buxus sempervirens), there are also characteristic aspects of its attack. In infested areas it has become impossible to maintain healthy shrubs without chemical treatments or mechanical destruction of larvae (laborious mechanical removal of larvae) (Kenis et al., 2013), as a result Cydalima perspectalis has and continues to have a strong impact on ornamental shrubs of common box.

Dasineura gleditschie, a North American originating species, was first reported in Europe in the Netherlands in 1975 (EPPO, 2008). In Romania, its introduction has not been observed, although it is 
considered to have been present since the 90 s (Olenici et al., 2008), a fact which is also confirmed by its presence in the southern part of the country (Nețoiu et al.,2018). Even though it is considered that Dasineura gleditschie can cause premature fall of the leaves and finally death of branches (Rosetta et al., 1998, Molnar et al., 2009) in the 6 locations where it was found, it did not cause significant damage, but only reduction of the aesthetic appearance of the host tree crown and the affected shoots.

The introduction of the invasive alien species Eopineus strobus in both Europe and Romania is still unknown, as various studies treat this aspect differently depending on the host species it has been identified on (Olenici and Duduman, 2016). However, it is considered to have been introduced in Europe in the same time with its host species, Pinus strobus (Steffan, 1972 cited by Olenici and Duduman, 2016)

In Bucharest, in the present study, the species was detected in only three of the six parks under study, not because of the limited spread of the insect but because of the fact that the host species, Pinus strobus, was not present in the rest of the parks. In this way, one can confirm the statement that the Eopineus strobus species is present almost everywhere where the host species is present as well (Olenici and Duduman, 2016).

Regarding the Obolodiplosis robiniae species, a North American species, this was first reported in Europe in 2003, in Italy (Duso et al., 2005) and in Romania in 2007 (Balint et al., 2010). Although this was present in all six parks in our study, galls produced by the insect were sporadically encountered in parks. Thus, we consider that apart from the black locust leaves degradation appearance, no significant impact was detected, but for the future it can be considered an important pest for black locust and severe damages can be found on trees (Balint et al., 2010).

Macrosaccus robiniella that came into Europe in 1983 in Switzerland (Whitebread, 1990) and Parectopa robiniella that entered Europe in 1970 in Italy (Vidano, 1970) are North American leafs miner species of that affect black locust trees. These are already common in Romania, being found both in Oltenia (Nețoiu, 2003; Nețoiu and Tomescu, 2006; Nețoiu et al., 2018) and Moldova (Ureche, 2006; Olenici and Duduman, 2016) and inside the Carpathian arch (Fodor and Hâruță, 2009). Even if the two species are considered to have negative physiological-primary effects both through the mines on the black locust leaf surface resulting from the feeding of the larvae and through the premature fall of the attacked leaves (Nețoiu and Tomescu, 2006; Hulujan et al., 2017), in Bucharest parks they did not cause significant damage, especially since they were not found in all 6 target locations.

Even though Nematus tibilis invasive alien species has American origin, it was first described in Europe, United Kingdom, in 1837 (Newman, 1837), and was recorded for the first time in Romania in 1958, in Calarasi (Scobiola, 1968). Although Nematus tibialis is a pest that did not have a significant effect on the black locust host trees, a greater attention should be given to the simultaneous attacks which are happening with the other three invasive alien species described above that are harmful to the black locust because it may affect the aesthetic appearance of the trees (Alford, 2012; Groot and Kavčič, 2017).

Prociphilus fraxinifolii is a species coming from North America and was first reported in Europe in 2003 in Budapest (Remaudière and Ripka 2003), and in Romania in 2017 (Nețoiu et al., 2018, Olenici et al., 2018). From our observations it seems that the only impact it has is an aesthetic one, more precisely large malformations called pseudo-galls, which are shaped on the ash leaves inside which were aphids' excrements. However, the recommendation consists in a higher attention given in the future to Prociphilus fraxinifolii species management, especially since the insect is considered to have not only aesthetic effects, but also effects on the natural regeneration of Fraxinus pennsylvanica trees species (Hałaj and Osiadacz, 2017).

Based on the results of this study and given the potential negative economic, ecological and social effects of invasive alien species, local authorities should intervene urgently to control the above mentioned species, especially that the existing urban vegetation in Bucharest must be preserved, protected and the plant health topic should be given a bigger importance (Ciceoi et al., 2017). 


\section{Conclusions}

After investigation in the six parks (Alexandru Ioan Cuza - IOR, Bucharest Botanical Garden, Cișmigiu Garden, King Michael I Park, USAMV Campus and Tineretului Park) in July 2019, 12 invasive insect species on woody plants were identified: Aproceros leucopoda, Cameraria ohridella, Corythucha arcuata, Corythucha ciliata, Cydalima perspectalis, Dasineura gleditchiae, Eopineus strobus, Macrosaccus robiniella, Nematus tibialis, Obolodiplosis robiniae, Parectopa robiniella, Prociphilus fraxinifoli. Of the 12 invasive insect species, none are new to Romania, but the species Aproceros leucopoda, Dasineura gleditchiae, Eopineus strobus, Macrosaccus robiniella, Nematus tibialis, Obolodiplosis robiniae, Parectopa robiniella, Prociphilus fraxinifoli are reported for the first time in Bucharest. Of all the host species affected by the invasive insects, only UImus minor, Quercus robur, Tilia spp. and Quercus cerris are native forest species, all others being foreign. Of all the parks under study, the King Michael I Park has the highest number of invasive insect species present from the investigated ones (10/12) while Cişmigiu Garden has the smallest number of invasive insect species present from the investigated ones (5/12). The local authorities should urgently intervene and control the invasive alien species on woody plants given the fact that their potential negative impact can have consequences on Bucharest citizens.

\section{Authors' Contributions}

Conceptualization: FB, AB, CN; Data curation; FB, DT, AA; Formal analysis: FB; Funding acquisition: $\mathrm{AB}$; Investigation: FB; Methodology: $\mathrm{FB}, \mathrm{AB}, \mathrm{CN}$; Project administration: FB, CN; Resources: FB, AB, DT, AA, CN; Software: AB; Supervision: FB, CN; Visualization: DT, AA; Writing - original draft: FB; Writing review and editing: $\mathrm{AB}, \mathrm{DT}, \mathrm{AA}, \mathrm{CN}$. All authors read and approved the final manuscript.

\section{Acknowledgements}

This work was supported by both the "Risk evaluation report on new species outbreak potential within deciduous Romanian forests" project, PN 19070201 and by the "Improvement of forests pests control method through modern technology usage" project, PN 19070202. We would like to thank to the three anonymous reviewers who made suggestions for improving the work and to Ms. Alexandra Bumbar for revising the English of the manuscript.

\section{Conflict of Interests}

The authors declare that there are no conflicts of interest related to this article.

\section{References}

Alford DV (2012). Pests of ornamental trees, shrubs and flowers: a colour handbook. Elsevier Academic Press 9:480. Bálint J, Neacșu P, Balog A, Fail J, Vetek G (2010). First record of the black locust gall midge, Obolodiplosis robiniae (Haldeman) (Diptera: Cecidomyiidae), in Romania. North-Western Journal of Zoology 6(2):319-322.

Bernardinelli I, Zandigiacomo P (2000). Prima segnalazione di Corythucha arcuata (Say) (Heteroptera, Tingidae) in Europa [First record of the oak lace bug Corythucha arcuata (Say) (Heteroptera, Tingidae) in Europe]. Informatore Fitopatologico 50(12):47-49. 
Blackburn TM, Essl F, Evans T, Hulme PE, Jeschke JM, Kühn I, ... Bacher S (2014). A unified classification of alien species based on the magnitude of their environmental impacts. PLOS Biology 12(5):e1001850. https://doi.org/10.1371/journal.pbio.1001850

Blank SM, Hara H, Mikulás J, Csóka G, Ciornei C, Constantineanu R, ... Vétek G (2010). Aproceros leucopoda (Hymenoptera: Argidae): An East Asian pest of elms (Ulmus spp.) invading Europe. European Journal of Entomology 107(3):357-367. https://doi.org/10.14411/eje.2010.045

Buszko J (2006). NOBANIS - Invasive alien species fact sheet - Cameraria ohridella. From: Online Database of the North European and Baltic Network on Invasive Alien Species - NOBANIS. Retrieved 2020 March 30 from www.nobanis.org.

Charles H, Dukes JS (2007). Impacts of invasive species on ecosystem services. In: Nentwig W (Eds). Biological Invasions. Ecological Studies (Analyses and Synthesis) 193:217-237 https://doi.org/10.1007/978-3-540-36920-2_13

Chiriac D, Humă C, Stanciu M (2009). Spațiile verzi - o problemă a urbanizării actuale [Green spaces - a problem of the current urbanization]. Calitatea Vieții 20(3-4):249-270.

Ciceoi R, Gutue C, Gutue M, Roșca I (2017). Current status of pests associated with urban vegetation in Bucharest area. Acta Zoologica Bulgarica 9:181-190

Colesca SE, Alpopi C (2011) The quality of Bucharest's green spaces. Theoretical and Empirical Researches in Urban Management 6(4):45-59.

Csóka G, Hirka A, Somlyai M (2013). A tölgy csipkéspoloska (Corythuca arcuata Say, 1832 - Hemiptera, Tingidae) első észlelése Magyarországon [First record of oak lace bug (Corythuca arcuata Say, 1832) in Hungary]. Növényvédelem 49(7):293-296.

Davis MA, Grime JP, Thompson K (2000). Fluctuating resources in plant communities: a general theory of invasibility. Journal of Ecology 88(3):528-534. https://doi.org/10.1046/j.1365-2745.2000.00473.x

Dioli P, Forini IG, Moretti M, Salvetti M (2007). Note sulla distribuzione di Corythucha arcuata (Insecta, Heteroptera, Tingidae) in Cantone Ticino (Svizzera), Valtellina e alto Lario (Lombardia, Italia) [Notes on the distribution of Corythucha arcuata (Say, 1832) (Insecta, Heteroptera, Tingidae) in the Alps and Pre-Alps of Lombardy (Italy) and Canton Ticino (Switzerland).]. Il Naturalista Valtellinese 18:59-68.

Dobreva M, Simov N, Georgiev G, Mirchev P, Georgieva M (2013). First record of Corythucha arcuata (Say) (Heteroptera: Tingidae) on the Balkan Peninsula. Acta Zoologica Bulgarica 65(3):409-412.

Don I, Don CD, Sasu LR, Vidrean D, Brad ML (2016). Insect pests on the trees and shrubs from Macea Botanical Garden. Studia Universitatis “Vasile Goldiș” Arad Seria Științe Inginerești și Agro-turism 11(2):23-28.

Duso C, Fontana P, Tirello P (2005). Diffusione in Italia e in Europa di Obolodiplosis robiniae (Haldeman), dittero cecidomiideneartico dannoso a Robinia pseudoacacia. [Spread of the gall midge Obolodiplosis robiniae (Haldeman) injurious to blacklocust in Italy and Europe]. Informatore Fitopatologico 55(5):30-33.

European Environment Agency (2012). The impacts of invasive alien species in Europe. Technical report no 16/2012. https://doi.org/10.2800/65864

European Environment Agency (2013). Invasive alien species: a growing problem for environment and health. Retrieved 2020 March 27 from https://www.eea.europa.eu/highlights/invasive-alien-species-a-growing

Eurostat (2012). Urban Europe - Statistics on cities, towns and suburbs. Green Cities.

Environmental Protection Agency (2006). 2016 Environmental Factors Status Report, Chapter 8 Urban Environmental EPPO (2008). Dasineura gleditchiae (Diptera: Cecidomyiidae): an invasive species in Europe. EPPO Reporting Service $11: 2008 / 224$.

Eritja R, Escosa R, Lucientes J, Marquès E, Molina R, Roiz D, Ruiz S (2005). Worldwide invasion of vector mosquitoes: present European distribution and challenges for Spain. Biological Invasions 7:87-97. https://doi.org/10.1007/1-4020-3870-4_8

Fodor E, Hâruța O (2009). Niche partition of two invasive insect species, Parectopa robiniella (Lepidoptera; Gracillariidae) and Phyllonorycter robiniella (Clem.) (Lepidoptera: Gracillariidae). Research Journal of Agricultural Science 41(2):261-269.

Forester B, Giacalone I, Moretti M, Diolt P, Waremelinger B (2005). Die amerikanische Eichennetzwanze Corythucha arcuata (Say) (Heteroptera, Tingidae) hat die Südschweiz erreicht [The american oak lace bug Corythucha arcuata (Say) (Heteroptera, Tingidae) has reached southern Switzerland]. Bulletin de la Société Entomologique Suisse 78:317-323. 
Gaertner M, Wilson JRU, Cadotte MW, Maclvor JS, Zenni RD, Richardson DM (2017). Non-native species in urban environments: patterns, processes, impacts and challenges. Biological Invasions 19(2):3461-3469. https://doi.org/10.1007/s10530-017-1598-7

Godefroid S (2001). Temporal analysis of the Brussels flora as indicator for changing environmental quality. Landscape and Urban Planning 52(4):203-224. https://doi.org/10.1016/S0169-2046(00)00117-1

Granbenweger G, Grill R, (2000). On the place of origin of Cameraria ohridella Deschka \& Dimic (Lepidoptera: Gracillariidae). Beiträge zur Entomofaunistik 1:9-17.

Groot MD, Kavčič A, (2017). Robinijeva grizlica, Nematus tibialis, nova tujerodna vrsta v Sloveniji [Nematus tibialis, a new non-native species in Slovenia]. Novice iz varstva gozdov 10:25-26.

Hałaj R, Osiadacz B (2017). Woolly ash aphid - is the alien bug posing a threat to European ash trees? - a review. Plant Protection Science 53:127-133.

Halbert S, Meeker J (1998). Sycamore lace bug, Corythucha ciliata (Say) (Hemiptera: Tingidae). Entomology Circular 387:1-2.

Hrašovec B, Posarić D, Lukić I, Pernek M (2013). Prvi nalaz hrastove mrežaste stjenice (Corythucha arcuata) u hrvatskoj [First record of oak lace bug (Corythucha arcuata) in Croatia]. Šumarski list 9(10):499-503.

Hulme PE (2014). Invasive species challenge the global response to emerging diseases. Trends in Parasitology 30(6):267270. https://doi.org/10.1016/j.pt.2014.03.005

Hulujan IB, Oltean I, Florian T (2017). Dynamics of the attack by Parectopa robiniella and Phyllonorycter robiniella of black locust from Valea lui Mihai and Covasna. Journal of Horticulture, Forestry and Biotechnology 21(3):96103.

Jeschke JM, Keesing F, Ostfeld RS (2013). Novel organisms: comparing invasive species, GMOs, and emerging pathogens. Ambio 42(5):541-548. https://doi.org/10.1007/s13280-013-0387-5

Juliano SA, Lounibos LP (2005). Ecology of invasive mosquitoes: effects on resident species and on human health. Ecology Letters 8(5):558-574. https://doi.org/10.1111/j.1461-0248.2005.00755.X

Jurc M, Jurc D (2017). Prvi Prvi nalaz i početak širenja hrastove mrežaste stjenice, Corythucha arcuata (Say, 1832) (Heteroptera: Tingidae), u Sloveniji [The first record and the beginning the spread of oak lace bug, Corythucha arcuata (Say, 1832) (Heteroptera: Tingidae), in Slovenia]. Šumarski list 9(10):485-488.

Kenis M, Auger-Rozenberg MA, Roques A, Timms L Péré C, Cock MJW, ... Lopez-Vaamonde C (2009). Ecological effects of invasive alien insects. Biological Invasions 11:21-45. https://doi.org/10.1007/s10530-008-9318-y

Kenis M, Nacambo S, Leuthardt FLG Domenico F Haye T (2013). The box tree moth, Cydalima perspectalis, in Europe: horticultural pest or environmental disaster? Aliens 33:38-41.

Kis B (1990). Corythucha ciliata (Heteroptera, Tingidae) un dăunător forestier nou pentru fauna României [Corythucha ciliata (Heteroptera, Tingidae) a new pest for the fauna of Romania]. Analele Banatului 2:320-321.

Kühn I, Klotz S (2006). Urbanization and homogenization-comparing the floras of urban and rural areas in Germany. Biological Conservations 127(3):292-300. https://doi.org/10.1016/j.biocon.2005.06.033

Krüger, EO (2008). Glyphodes perspectalis (Walker, 1859) - neu für die Fauna Europas (Lepidoptera: Crambidae) [Glyphodes perspectalis (Walker, 1859) - new for the European fauna (Lepidoptera: Crambidae)]. Entomologische Zeitschrift 118(2):81-83.

Lounibos LP (2002). Invasions by insect vectors of human disease. Annual Review of Entomology 47:233-266. https://doi.org/10.1146/annurev.ento.47.091201.145206

Lovell SJ, Stone SF, Fernendez L (2006). The economic impacts of aquatic invasive species: a review of the literature. Agricultural and Resource Economics Review 35(1):195-208. https://doi.org/10.1017/S1068280500010157

Malumphy C, Reid S, Dominic E (2006). Platanus lace bug Corythucha ciliata. Plant Pest Notice 36:1-4.

McKinney ML (2006). Urbanization as a major cause of biotic homogenization. Biological Conservation 127(3):247260. https://doi.org/10.1016/j.biocon.2005.09.005

Meyerson LA, Mooney HA (2007). Invasive alien species in an era of globalization. Frontiers in Ecology and the Environment 5(4):199-208. https://doi.org/10.1890/1540-9295(2007)5[199:IASIAE]2.0.CO;2

Molnar B, Boddum T, Szőcs G, Hillbur Y (2009). Occurrence of two pest gall midges, Obolodiplosis robiniae(Haldeman) and Dasineura gleditchiae (Osten Sacken) (Diptera: Cecidomyiidae) on ornamental trees in Sweden. Entomologisk Tidskrift 130(2):113-120

Mutun S, Ceyhan Z, Sözen C, (2009). Invasion by the oak lace bug, Corythucha arcuata (Say) (Heteroptera: Tingidae) in Turkey. Turkish Journal of Zoology (33):263-268. https://doi.org/10.39.06/zoo-0806-13 
Neimorovets VV, Shchurov VI, Bondarenko AS, Skvortsov MM, Konstantinov FV (2017). First documented outbreak and new data on the distribution of Corythucha arcuata (Say, 1832) (Hemiptera: Tingidae) in Russia. Acta Zoologica Bulgarica 9:139-142.

Nentwig W, Mebs D, Vila M (2017) Impact of non-native animals and plants on human health. In: Vila M, Hulme P (eds) Impact of biological invasions on ecosystem services. Springer, Cham pp 277-294. https://doi.org/10.1007/978-3-319-45121-3_18

Nețoiu C (2003). O nouă molie minieră a salcâmului din România: Phyllonorycter robiniella Clemens, 1859 (Lepidoptera: Gracillarridae) [A new miner's moth of black locust in Romania: Phyllonorycter robiniella Clemens, 1859 (Lepidoptera: Gracillarridae)]. Oltenia. Studii și comunicări. Muzeul Olteniei Craiova 19:154156.

Nețoiu C, Tomescu R (2006). The leaf miners of black locust (Parectopa robiniella Clemens - 1863 and Phyllonorycter robiniella Clemens 1859, Lepidoptera, Gracillariidae. Analele ICAS 49:119-131.

Nețoiu C, Tomescu R, Olenici N, Buzatu A, Bălăcenoiu F, Iliescu O (2018). The invazive insect species in the Oltenia Region (Romania). Oltenia. Studii și comunicări. Muzeul Olteniei Craiova 34(1):111-123.

Newman E (1837). Notes on Tenthredinina. The Entomological Magazine 4:258-263.

Olenici N, Duduman ML (2016). Noi semnalări ale unor specii de insecte forestiere invazive în România. [New records of some invazive forest insect species in Romania]. Bucovina Forestieră 16(2):161-174. https://doi.org/10.4316/bf.2016.015

Olenici N, Blaga T, Tomescu R, Gogu I, Țilea Ghe (2018). Cinci specii de insecte forestiere invazive în partea de nord-est a României [Five new invasive forest insect species in the north-eastern part of Romania]. Bucovina Forestieră 18(2):119-135. https://doi.org/10.4316/bf.2018.013

Pimentel D, Lach L, Zuniga R, Morrison D (2000). Environmental and economic costs of nonindigenous species in the United States. BioScience 50(1):53-65. https://doi.org/10.1641/0006 3568(2000)050[0053:EAECON]2.3.CO;2

Rabitsch W (2008). Alien true bugs of Europe (Insecta: Hemiptera: Heteroptera). Zootaxa 1827:1-44. https://doi.org/10.11646/zootaxa.1827.1.1

Remaudière G, Ripka G (2003). Arrivée en Europe (Budapest, Hongrie) du puceron des frenes américains, Prociphilus (Meliarhizophagus) fraxinifolii (Hemiptera, Aphididae, Eriosomatinae, Pemphigini). Revue Française d'Entomologie 25(3):152.

Rosetta RL, Thompson P, Bell N (1998). IPM of honey pod gall midge. The Digger 42(3):34-36.

Roques A (2010). Taxonomy, time and geographic patterns. Chapter 2. In: Roques A et al. (Eds) Alien terrestrial arthropods of Europe. BioRisk 4(1):11-26. https://doi.org/10.3897/biorisk.4.70

Roques A, Auger-Rozenberg MA, Blackburn TM, Garnas J, Pysel P, Rabitsch W, ... Duncan RP (2016). Temporal and interspecific variation in rates of spread for insect species invading Europe during the last 200 years. Biological Invasions 18(4):907-920. https://doi.org/10.1007/s10530-016-1080-y

Schindler S, Staska B, Adam M, Rabitsch W, Essl F (2015). Alien species and public health impacts in Europe: a literature review. NeoBiota 27:1-23. https://doi.org/10.3897/neobiota.27.5007

Scobiola PX (1968). Contributions a l'étude des Hyménopteres de la région sudique de la Valachie. [Contributions to the study of Hymenoptera from the southern Wallachia region]. Travaux du Museum National d'Histoire Naturelle „Grigore Antipa" 9:369-393.

Shochat E, Lerman SB, Anderies JM, Warren PS, Faeth SH, Nilon CH (2010). Invasion, competition, and biodiversity loss in urban ecosystems. BioScience 60(3):199-208. https://doi.org/10.1525/bio.2010.60.3.6

Simberloff D, Martin JL, Genovesi P, Maris V, Wardle DA, Aronson J, ... Vilà M (2013). Impacts of biological invasions: what's what and the way forward. Trends in Ecology \& Evolution 28(1):58-66. https://doi.org/10.1016/j.tree.2012.07.013

Simov N Grozeva S, Langourov M, Georgieva M, Mirchev P, Georgiev G, (2018). Rapid expansion of the Oak lace bug Corythucha arcuata (Say, 1832) (Hemiptera: Tingidae) in Bulgaria. Historia Naturalis Bulgarica 27:51-55.

Skuhravy V (1998). Zur kenntnis der Blattminen-Motte Cameraria ohridella Deschka \& Dimic (Lep., Lithocolletidae) an Aesculus hippocastanum L. in der Tschechischen Republik. Anzeiger für Schädlingskunde, Pflanzenschutz und Umweltschutz 71(5):81-84.

Smith S, Johnson T (2018). Health benefits of apple. In: Skipper T (Ed). Apple production. Frenches Press NSW Pearson Education Australia pp 281-299. 
Steffan AW (1972). Unterordnung Aphidina - Blattläuse. In: Schwenke W (ed.): Die Forstschädlinge Europas. 1. Band - Würmer, Schnecken, Spinnentiere, Tausendfüssler und hemimetabole Insekten. [The forest pests in Europe. Volume 1 - worms, snails, arachnids, millipedes and hemmimetabolic insects]. Verlag Paul Parey, Hamburg und Berlin, pp 162-386.

Șandru ID (1999). Larva minieră a frunzelor de castan (Cameraria ohridella). [Horsechestnut leafminer (Cameraria ohridella)]. Sănătatea Plantelor 6:29.

Tatu AI, Tăușan I (2011). Corythucha ciliata (Say, 1832) (Hemiptera: Tingidae) - Second record for the lace bug fauna of Romania. Brukenthal Acta Musei VI(3):453-458.

Tobin PC (2018). Managing invasive species [version 1; peer review: 2 approved]. F1000Research 7:1686. https://doi.org/10.12688/f1000research.15414.1

Tomescu R, Olenici N, Nețoiu C, Bălăcenoiu F, Buzatu A (2018). Invasion of the oak lace bug Corythucha arcuata (Say.) in Romania: a first extended reporting. Annals of Forest Research 61(2):161-170. https://doi.org/10.15287/afr.2018.1187

Trentanovi G, von der Lippe M, Sitzia T, Ziechmann U, Kowarik I, Cierjacks A (2013). Biotic homogenization at the community scale: disentangling the roles of urbanization and plant invasion. Diversity and Distributions 19(7):738-748. https://doi.org/10.1111/ddi.12028

Ureche C (2006). Invasive leaf miner insects in Romania, Proc. the 7th Workshop on Methodology of Forest Insect and Disease Survey in Central Europe, IUFRO Working Party 7.03.10, Gmunden, Austria, September 11-14, 2006, pp 259-262.

van Vilgen BW (2012). Evidence, perception and trade-offs associated with invasive alien plant control in the Table Mountain National Park, South Africa. Ecology and Society 17(2):23. https://doi.org/10.5751/ES-04590170223

Vidano C (1970). Foglioline di Robinia pseudoacacia con mine di un microlepidopttero nuotare per l'Italia. Leafs of Robinia pseudoacacia with mines of a microlepidopter. L'Apicoltore Moderno 61(10):1-2

Vilà M, Espinar JL, Hejda M, Hulme PE, Jarosík V, Maron JL, ... Pyšek P (2011). Ecological impacts of invasive alien plants: a meta-analysis of their effects on species, communities and ecosystems. Ecology Letters 14(7):702-708. https://doi.org/10.1111/j.1461-0248.2011.01628.X

Vilà M, Basnou C, Pyšek P, Josefsson M, Genovesi P, Gollasch S, ... DAISIE partners (2010). How well do we understand the impacts of alien species on ecosystem services? A pan-European, cross-taxa assessment. Frontiers in Ecology and the Environment 8(3):135-144. https://doi.org/10.1890/080083

Wania A. Kuhn I, Klotz S (2006). Plant richness patterns in agricultural and urban landscapes in central Germany spatial gradients of species richness. Landscape and Urban Planning 75(1-2):97-110. https://doi.org/10.1016/j.landurbplan.2004.12.006

Whitebread SE (1990). Phyllonorycter robiniella (Clemens 1859) in Europe (Lepidoptera, Gracillariidae). Nota Lepidopterologica 12(4):344-353.

Williamson M, Fitter A (1996). The varying success of invaders. Ecology 77(6):1661-1666. https://doi.org/10.2307/2265769
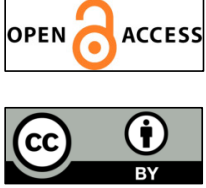

The journal offers free, immediate, and unrestricted access to peer-reviewed research and scholarly work. Users are allowed to read, download, copy, distribute, print, search, or link to the full texts of the articles, or use them for any other lawful purpose, without asking prior permission from the publisher or the author.

License - Articles published in Notulae Botanicae Horti Agrobotanici Cluj-Napoca are Open-Access, distributed under the terms and conditions of the Creative Commons Attribution (CC BY 4.0) License. (c) Articles by the authors; UASVM, Cluj-Napoca, Romania. The journal allows the author(s) to hold the copyright/to retain publishing rights without restriction. 